\title{
Spontaneous Symmetry-Breaking in the Corrosion Transformation of Ancient Bronzes
}

\author{
Yanpeng Yang ${ }^{1,+}$, Xiaojuan Cao ${ }^{1,+}$, Yang $\mathrm{Li}^{2,+}$, Zhongchi Wang ${ }^{1}$, Bingjie Li ${ }^{1}$, Xudong Jiang ${ }^{3}$, \\ Junji Jia ${ }^{4}$ and Chunxu Pan $1,5, *$ (D) \\ 1 School of Physics and Technology, and MOE Key Laboratory of Artificial Micro- and Nano-Structures, \\ Wuhan University, Wuhan 430072, China; yangshu@whu.edu.cn (Y.Y.); 18435207376@163.com (X.C.); \\ jackwzc@whu.edu.cn (Z.W.); 15827426251@163.com (B.L.) \\ 2 School of History, Wuhan University, Wuhan 430072, China; liyang19830703@126.com \\ 3 Hubei Provincial Museum, Wuhan 430077, China; jiangwhu@hotmail.com \\ 4 Center for Theoretical Physics, Wuhan University, Wuhan 430072, China; junjijia@gmail.com \\ 5 Center for Electron Microscopy, Wuhan University, Wuhan 430072, China \\ * Correspondence: cxpan@whu.edu.cn \\ $\dagger$ These authors contributed equally to this work.
}

Received: 2 July 2020; Accepted: 21 July 2020; Published: 24 July 2020

check for updates

\begin{abstract}
In general, during long-term museum conservation, ancient bronzes will generate new corrosion products also called the "secondary corrosion" on the surface of the unearthed "primary corrosion" products due to various environmental conditions. In this paper, the corrosion stages of several ancient Chinese bronzes are characterized by using optical microscope (OM), scanning electron microscope (SEM), energy dispersive spectrometer (EDS), X-ray diffraction (XRD) and Raman spectrometer (Raman). It is found that there exist phase transformation relationships in between the "primary corrosion" and the "secondary corrosion" stages (i.e., (1) the crystal lattice type tends to transform from a high symmetry system to a low symmetry system; (2) in case of the same crystal lattice type, the corrosions exhibit an inter-transformation or symbiosis). It is interesting to note that these transformation rules are very consistent with the well-known physical law of "spontaneous symmetry-breaking", which won the 2008 Nobel Prize in Physics and also has been considered to be general law of nature, in addition to the principle of Gibbs free energy reduction. The significance of this discovery allows us to achieve the predictability and controllability of the bronze corrosion products (i.e., to predict the corrosive trends in advance and control the "second corrosion" by adjusting the conservation conditions. This research provides a novel conservation concept of ancient bronzes.
\end{abstract}

Keywords: ancient bronze; primary corrosion; secondary corrosion; phase transformation; crystallographic analysis; spontaneous symmetry-breaking

\section{Introduction}

Ancient Chinese bronzes are the treasures of Chinese cultural relics, which mostly represent the splendid bronze civilization of the dynasties Xia, Shang and Zhou from 2070 BC to 221 BC. Throughout several millennia of soil burial or conservation in variant environmental conditions, different corrosion products are generated. In general, these corrosion products can be divided into two sorts (i.e., harmless and harmful to the bronzes [1]). Harmless corrosion refers to a process in which the corrosion products will not further penetrate into the bronze body during conservation. However, harmful corrosion appears in the form of a white-green powder, also called the "powdery corrosion" or "bronze disease" [2], which consists of the reactive cuprous chloride $(\mathrm{CuCl})$ species and 
can further form the greenish $2 \mathrm{Cu}_{2}(\mathrm{OH})_{3} \mathrm{Cl}$ (atacamite and its polymorphs) in humid environments continuously, and finally damage the whole bronzes [3]. Therefore, the harmful products must be properly treated as early as possible, and many researchers have engaged in this study for many years.

The corrosion mechanism of ancient bronzes is a crucial theoretical basis for conservation, and many mechanisms have been proposed from physical and chemical perspectives [3-5], such as pitting corrosion [6-8], crevice corrosion, intergranular corrosion $[9,10]$ and selective phase corrosion [11,12], etc.

In general, the unearthed ancient bronzes are collected and conserved in museums, or by private collectors, which are mostly exposed to the atmosphere. In most cases, the "secondary corrosion" will uncontrollably generate upon the existed "primary corrosion" products, due to the complicated environmental conditions, such as humidity, nonmetallic ion concentration and harmful gases, etc. $[13,14]$. Some of them are relatively stable and harmless, but some will continue to grow and accelerate the corrosion process and cause irreversible damage, which is still a challenge in the protection of ancient bronzes. Therefore, research on the growth mechanism of the "secondary corrosion" and the relationships with the "primary corrosion" has great theoretical and practical significances.

The "spontaneous symmetry-breaking" is considered as a general law in physics and even in nature and won the Nobel Prize in Physics in 2008 [15]. It describes the phenomenon that an original system with high symmetry has asymmetric factors and tends spontaneously to a low degree of symmetry. It can also be written as: when the control parameter $\lambda$ crosses a certain critical value, the original state of the system with high symmetry becomes unstable, and several equivalent stable states with low symmetry will appear, and then the system will transit to one of them. Many studies have demonstrated that simple phase state or phase transformations of substances, such as crystals, magnets, general superconductors, etc. can be understood from the "spontaneous symmetry-breaking" perspective $[16,17]$. Broadly speaking, order is relative, temporary and subordinate, while disorder is absolute, steady-state and free in nature. Without symmetry-breaking, the world would be lifeless, dull, pallid and devoid of life. There are also many examples of the "spontaneous symmetry-breaking" phenomenon-for instance, parity non-conservation under weak force, asymmetry between particles and antiparticles, symmetry-breaking of chiral molecules, etc. In fact, it can also happen in many other areas, including chemistry, biology, geography, astronomy and sociology. In addition, the "spontaneous symmetry-breaking" theory also indicates that the possibility of asymmetry is closely related to the intrinsic symmetry (i.e., the more intrinsic symmetry there is, the more possible asymmetry will appear [18]).

In this paper, we introduce a novel discovery that the relationship between the ancient bronze's "primary corrosion" and "secondary corrosion" agrees with the law of "spontaneous symmetry-breaking". That is, the crystal lattice types of the "primary corrosion" with a high symmetry system exhibits a spontaneous transformation direction to a low symmetry system of the "secondary corrosion" during long-term conservation, and in the case of transformation in-between the same crystal lattice type, the corrosion products will have an inter-transformation or symbiosis. The significance of this finding allows us to achieve the predictability and controllability of bronze corrosion stages, and to provide ideas for corrosion removal and later protection of ancient bronzes.

\section{Experimental}

The ancient bronze samples are mainly from the Wuhan Museum and the Anlu Museum of the Hubei province in China, which were initially unearthed from different buried environments. The detailed information is listed in Table 1. The detailed images and the corresponding locations for examination are shown in Figure 1. 
Table 1. Information of the ancient bronzes.

\begin{tabular}{ccccc}
\hline Name & $\begin{array}{c}\text { Collection Number in } \\
\text { the Museums }\end{array}$ & Period & Burial Conditions & Sampling Position \\
\hline Bronze vase $(\mathrm{Gu})$ & ABG-2209-1 & $\begin{array}{c}\text { Shang Dynasty } \\
(1600 \mathrm{BC}-1046 \mathrm{BC})\end{array}$ & Soil & $\begin{array}{c}\text { Mouth edge, as } \\
\text { shown in Figure 1a }\end{array}$ \\
\hline $\begin{array}{c}\text { Bronze goblet }(\mathrm{Jue} \\
\text { Bei })\end{array}$ & 3253 & $\begin{array}{c}\text { Shang Dynasty } \\
(1600 \text { BC-1046 BC })\end{array}$ & Tomb & $\begin{array}{c}\text { Mouth edge, as } \\
\text { shown in Figure 1b }\end{array}$ \\
\hline $\begin{array}{c}\text { Bronze basin }(\mathrm{Fu}) \\
\text { Bronze vessel } \\
(\text { Ding })\end{array}$ & ABF-5155 & $\begin{array}{c}\text { Spring and } \\
\text { Autumn Period } \\
(770 \text { BC-476 BC })\end{array}$ & Soil & $\begin{array}{c}\text { Mouth edge, as } \\
\text { shown in Figure 1c }\end{array}$ \\
\hline $\begin{array}{c}\text { Western Han } \\
\text { Dynasty } \\
\text { Bronze sword }\end{array}$ & 1233 BC-25 AD) & Soil & $\begin{array}{c}\text { Bottom, as shown } \\
\text { in Figure 1d }\end{array}$ \\
\hline Bronze bowl $(\mathrm{Bo})$ & 3638 & $\begin{array}{c}\text { Western Han } \\
\text { Dynasty } \\
(202 \text { BC-25 AD) }\end{array}$ & Tomb & $\begin{array}{c}\text { Blade tip, as shown } \\
\text { in Figure 1e }\end{array}$ \\
\hline
\end{tabular}

(a)
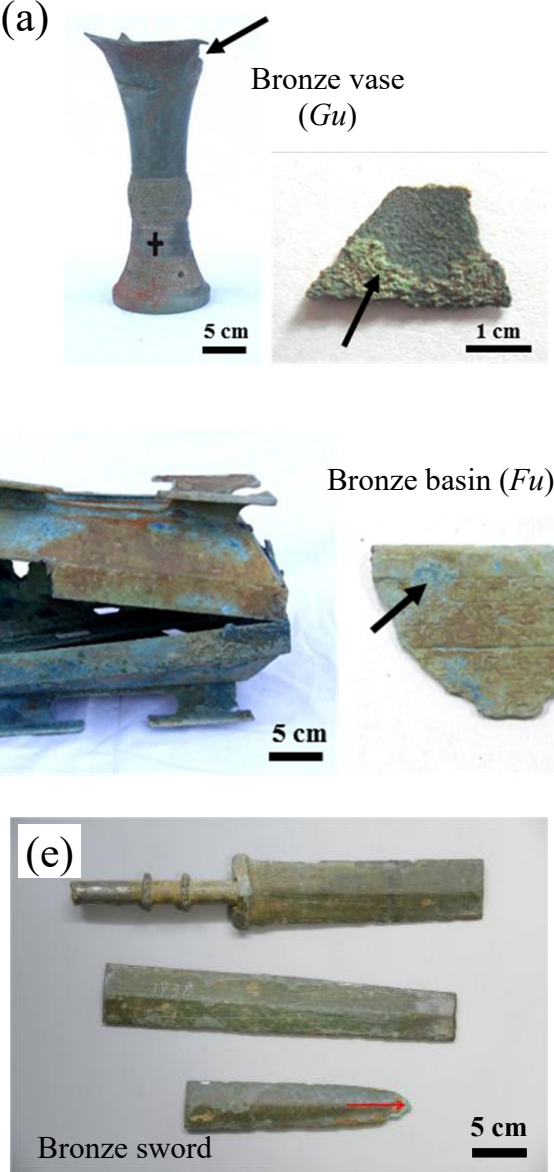



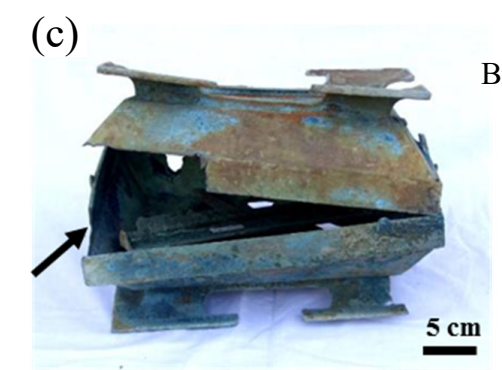

Bronze basin $(F u)$

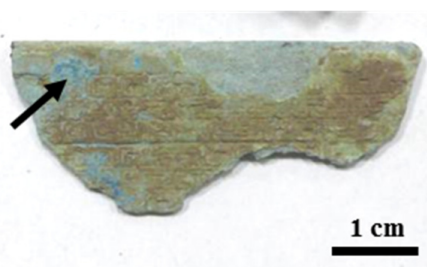



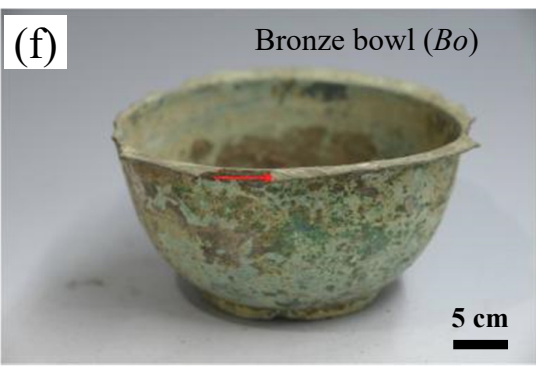

Figure 1. Images of the ancient bronzes—-the arrows indicate the sampling position: (a) Bronze vase (Gu) (Shang Dynasty, collection No.: ABG-2209-1); (b) Bronze goblet (Jue Bei) (Shang Dynasty, collection No.: 3253); (c) Bronze basin (Fu) (Spring and Autumn Period, collection No.: ABF-5155); (d) Bronze vessel (Ding) (Western Han Dynasty, collection No.: 1233); (e) Bronze sword (Western Han Dynasty, collection No.: 1938); (f) Bronze bowl (Bo) (Tang Dynasty, collection No.: 3668).

Before examination, firstly, the bronze relics were ultrasonically cleaned in ethanol solution for 5-10 min for removing surface impurities, blemishes, muddiness and foreign substances. Then, 
the samples were used for stereomicroscope observation, X-ray diffraction (XRD) and Raman analysis. At last, the samples were mounted on the specimen stage by using conductive silver for high-magnification observation and chemical composition measurement by using scanning electron microscope (SEM) and energy-dispersive X-ray spectroscopy (EDS). Due to the better conductivity of bronze, the sample's surface was not carried on the gold or carbon coating, because it would have an additional influence on the corrosion compositions.

The macro-morphologies of the samples were observed by Leica DM2700M metallographic microscope (OM). The crystalline phases of the corrosion products were measured by using a X-ray diffraction spectrometer (XRD) (D8 Advance, Bruker AXS, Germany) with Cu K $\alpha$ radiation and a scanning speed of $4^{\circ} / \mathrm{min}$ in a range of $20-90^{\circ}$, and a laser scanning confocal micro-Raman spectrometer (Raman) (LabRAM HR, HORIBA, France) with a laser excitation wavelength of $488 \mathrm{~nm}$ and scans on an extended range of $100-4000 \mathrm{~cm}^{-1}$. The microstructural observations and chemical compositions of the samples were carried out by using scanning electron microscope (SEM) (SIRON, FEI, The Netherlands) equipped with an energy-dispersive X-ray spectroscopy (EDS), accelerating the voltage to $20 \mathrm{kV}$. The area-scanning was used to measure the average chemical compositions.

\section{Results}

In this part, these six ancient bronzes were instrumentally examined for identifying the nature of the corrosion stages attached to the surface (i.e., "primary corrosion" or "secondary corrosion"), from aspects involving microstructures, crystal lattice types, chemical compositions and co-existing relationships.

\subsection{Corrosions on the Bronze Vase (Gu)}

Figure 2 shows the experimental results of the bronze vase $(G u)$ (Shang Dynasty, around 1600 BC-1046 BC, collection no.: ABG-2209-1). Obviously, there existed two kinds of corrosion products (i.e., a dark green corrosion covered with a light green), as shown in Figure 2a. SEM observations showed that the portion of the dark green was composed of irregular grains, while the light green was mainly fibrous clusters with a high degree of crystallinity, as shown in Figure 2b,c. EDS measurements revealed that the chemical compositions of the dark green contained $\mathrm{Cu}, \mathrm{Sn}, \mathrm{C}$ and $\mathrm{O}$ elements, as well as $\mathrm{Fe}, \mathrm{K}$ and $\mathrm{Ca}$ elements from the soil. However, the chemical compositions of the light green only had $\mathrm{Cu}, \mathrm{C}$ and $\mathrm{O}$ elements. By comparing these chemical compositions and considering their co-existing and stacking relation, it could be confirmed that the dark green corrosion belonged to the "primary corrosion" stage, while the light green without any impurity elements was the "secondary corrosion" stage, which was generated during museum storage. Powder XRD identification indicated that the phases contained corrosion products, including cuprite $\left(\mathrm{Cu}_{2} \mathrm{O}\right)$, cassiterite $\left(\mathrm{SnO}_{2}\right)$ and malachite $\left(\mathrm{CuCO}_{3} \cdot \mathrm{Cu}(\mathrm{OH})_{2}\right)$, as shown in Figure $2 \mathrm{~d}$.

Further Raman spectra revealed that the dark green product was a mixture of cuprite and cassiterite, as shown in Figure 2e, while the light green was malachite, as shown in Figure 2f,g. Therefore, it could be confirmed that the "primary corrosion" stages were mainly composed of cuprite and cassiterite with few other amorphous mixtures, while the "secondary corrosion" stage was malachite, which was developed during soil burial and museum conservation, respectively. 


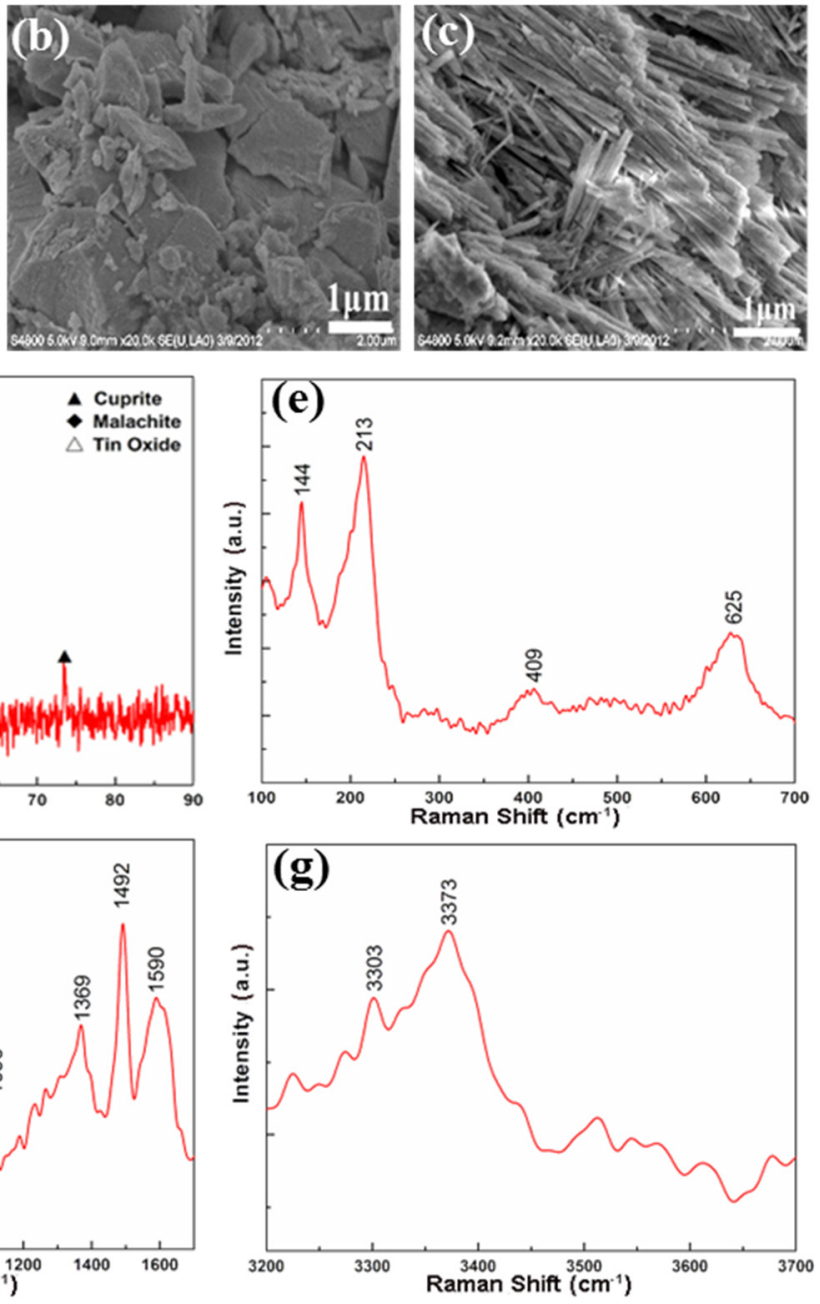

Figure 2. Characterizations of the corrosion products upon the bronze vase ( $\mathrm{Gu}$ ) (Shang Dynasty, collection No.: ABG-2209-1): (a) Optical image; (b) SEM morphology of the dark green corrosion; (c) SEM morphology of the light green corrosion; (d) XRD pattern; (e) Raman spectrum of the dark green corrosion; (f,g) Raman spectra of the light green corrosion in ranges $100-1700 \mathrm{~cm}^{-1}$ and $3200-3700 \mathrm{~cm}^{-1}$, respectively.

\subsection{Corrosions on the Bronze Goblet (Jue Bei)}

Figure 3 shows experimental results of the corrosion products on the surface of the bronze goblet (Jue Bei) (Shang Dynasty, around 1600 BC-1046 BC, collection no.: 3253). From optical observation, the surface was covered mainly by a kind of light green corrosion product with few red corrosion products, as shown in Figure 3a. SEM observed that the corrosion products exhibited a laminate structure and contained a large number of fine bulk crystals. EDS measurement showed the elements $\mathrm{Cu}, \mathrm{O}, \mathrm{Sn}$ and $\mathrm{Pb}$ within the corrosions. 



Figure 3. Characterizations of the corrosion products upon the bronze goblet (Jue Bei) (Shang Dynasty, collection No.: 3253): (a) Optical image; (b) SEM morphology; (c) Raman spectrum of the red corrosion product (cuprite) in a range $100-1000 \mathrm{~cm}^{-1}$; (d) Raman spectrum of the light green corrosion product (malachite) in a range $100-3500 \mathrm{~cm}^{-1}$.

Raman spectra revealed that the red product belonged to cuprite $\left(\mathrm{Cu}_{2} \mathrm{O}\right)$, as shown in Figure $3 \mathrm{c}$, while the light green belonged to malachite $\left(\mathrm{CuCO}_{3} \cdot \mathrm{Cu}(\mathrm{OH})_{2}\right)$, as shown in Figure 3d. However, further detailed analysis found that there was a pronounced free water $\mathrm{H}-\mathrm{O}-\mathrm{H}$ bending vibration peak at $1602 \mathrm{~cm}^{-1}$, and the corresponded malachite was poor in crystallinity, in which no soil impurity of Si element was obtained. That is to say, this malachite belonged to the "secondary corrosion" stage formed during museum conservation.

\subsection{Corrosions on the Bronze Basin (Fu)}

Figure 4 gives experimental results of the corrosion products on the surface of the bronze basin (Fu) (Spring and Autumn Period, around 770 BC-476 BC, collection No.: ABF-5155). Obviously, the surface was dominated by green corrosion product accompanied with few blue corrosion products, as shown in Figure 4a. Further SEM observations in high magnification showed that the blue product was composed of irregularly shaped grains, while the green was a mixture of irregularly shaped grains and fibrous clusters, and had good crystallization, as shown in Figure 4b,c EDS measurements indicated that the chemical compositions of the green corrosion product contained elements including $\mathrm{Cu}, \mathrm{Sn}$, $\mathrm{Pb}, \mathrm{C}$ and $\mathrm{O}$, as well as impurities, such as $\mathrm{Si}$ and $\mathrm{Al}$, which demonstrated it as the "primary corrosion" stage generated in the soil burial environment. However, the blue corrosion product mainly contained $\mathrm{Cu}, \mathrm{C}$ and $\mathrm{O}$ element without any impurities, which suggested it as the "secondary corrosion" stage, formed after entering the museum. Powder XRD identification revealed the corrosion phases, including cuprite $\left(\mathrm{Cu}_{2} \mathrm{O}\right)$, cassiterite $\left(\mathrm{SnO}_{2}\right)$, malachite $\left(\mathrm{CuCO}_{3} \cdot \mathrm{Cu}(\mathrm{OH})_{2}\right)$ and azurite $\left(2\left(\mathrm{CuCO}_{3}\right) \cdot \mathrm{Cu}(\mathrm{OH})_{2}\right)$, as shown in Figure 4d. 

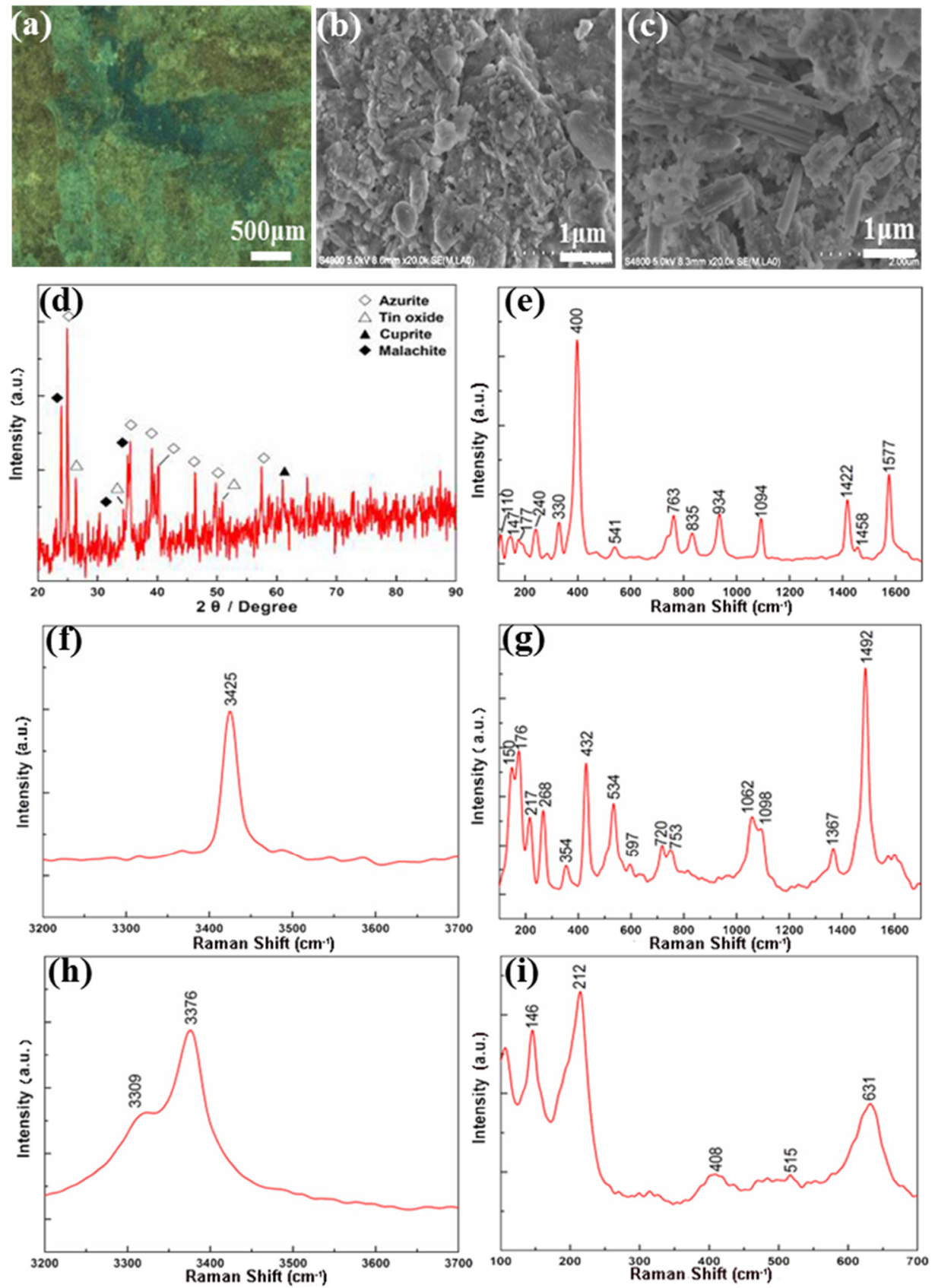

Figure 4. Characterizations of the corrosion products upon the bronze basin (Fu) (Spring and Autumn Period, collection No.: ABF-5155): (a) Optical image; (b) SEM morphology of the blue corrosion product; (c) SEM morphology of the green corrosion product; (d) XRD pattern; (e,f) Raman spectra of the blue corrosion product (azurite) in ranges $100-1700 \mathrm{~cm}^{-1}$ and $3200-3700 \mathrm{~cm}^{-1}$, respectively; (g,h) Raman spectra of the green corrosion product (malachite) in ranges $100-1700 \mathrm{~cm}^{-1}$ and $3200-3700 \mathrm{~cm}^{-1}$, respectively; (i) Raman spectrum of the green corrosion product (cuprite and cassiterite) in a range $100-700 \mathrm{~cm}^{-1}$.

Raman spectra indicated that the blue and green corrosions exactly fitted the standard peaks of azurite [19,20], as shown in Figure $4 \mathrm{e}, \mathrm{f}$ and malachite $\left(\mathrm{CuCO}_{3} \cdot \mathrm{Cu}(\mathrm{OH})_{2}\right)$, as shown in Figure $4 \mathrm{~g}, \mathrm{~h}$, respectively. In addition, it was also found that some peaks from the green corrosion could be ascribed to cuprite and cassiterite, as shown in Figure 4i. That is to say, the green corrosion was a mixture of cuprite, cassiterite and malachite, which had formed before it entered the museum, and the blue 
corrosion azurite was a newly formed "secondary corrosion" stage during museum conservation. This conclusion also matched the museum records.

\subsection{Corrosions on the Bronze Vessel (Ding)}

Figure 5 illustrates experimental results of the surface corrosion products upon the bronze vessel (Ding) (Western Han Dynasty, 202 BC-25 AD, collection No.: 1233). The most part of the bronze appeared a kind of light green surface without powdery harmful corrosion substance, as shown in Figure 5a. SEM observation also showed a flat and smooth surface with a dense microstructure and many small crystals with a high degree of crystallinity, as shown in Figure 5b. EDS measurement revealed the chemical composition, containing $\mathrm{Cu}, \mathrm{O}$, and $\mathrm{C}$ elements.
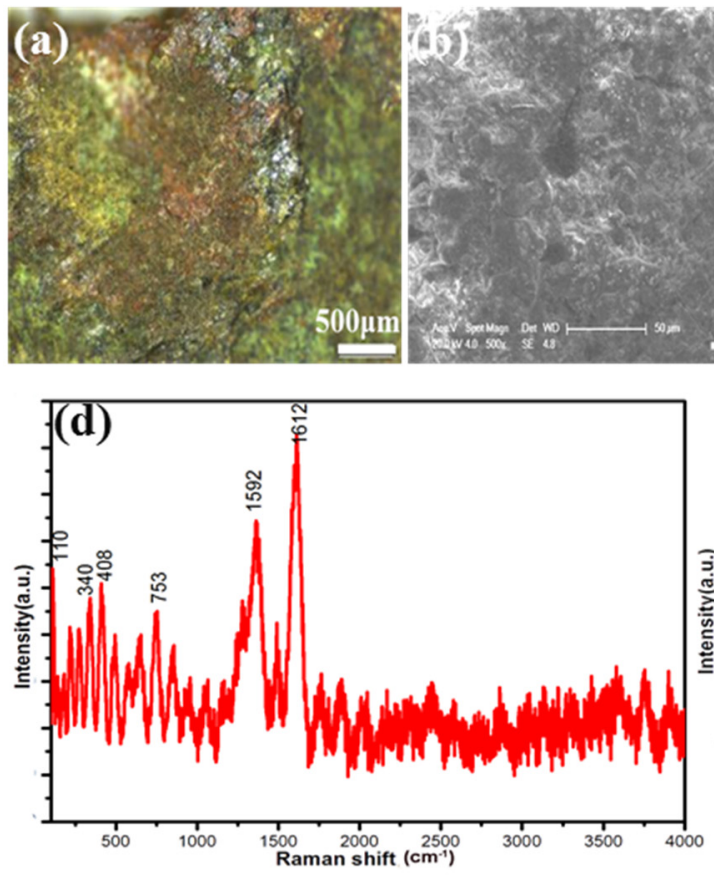


Figure 5. Characterizations of the corrosion products upon the bronze vessel (Ding) (Western Han Dynasty, collection No.: 1233): (a) Optical image; (b) SEM morphology; (c) Raman spectrum of malachite in a range $100-3500 \mathrm{~cm}^{-1}$; (d) Raman spectrum of azurite in a range $100-3500 \mathrm{~cm}^{-1}$; (e) Raman spectrum of carbon in a range $100-2000 \mathrm{~cm}^{-1}$.

Raman spectra indicated that the corrosion products included not only malachite $\left(\mathrm{CuCO}_{3} \cdot \mathrm{Cu}(\mathrm{OH})_{2}\right)$, as shown in Figure $5 \mathrm{c}$ and azurite $\left(2\left(\mathrm{CuCO}_{3}\right) \cdot \mathrm{Cu}(\mathrm{OH})_{2}\right)$, as shown in Figure $5 \mathrm{~d}$, but also a carbonaceous substance, as shown in Figure 5e. That is to say, the co-existence of a carbonaceous substance and the poor crystallized malachite demonstrated that the bronze vessel (Ding) might have been practically used during the Western Han Dynasty and corroded during the long-term burial in the soil and, therefore, it could be classified as the "primary corrosion" stage. However, for the azurite, the Raman peak of bound water was missing, and the peak of free water $\mathrm{H}-\mathrm{O}-\mathrm{H}$ bending vibration at $1612 \mathrm{~cm}^{-1}$ was very strong, which made it a possibility of the "secondary corrosion" stage formed during the later museum collection environment. This conclusion also matched the museum records. It also revealed the improper museum conservation conditions, such as unstable humidity and high $\mathrm{CO}_{2}$ concentration, which could have caused a corrosion transformation from malachite into azurite [21].

\subsection{Corrosions on the Bronze Sword}

Figure 6 gives experimental results of the corrosion products on the surface of the bronze sword (Western Han Dynasty, 202 BC-25 AD, collection No.: 1938). Obviously, the surface was mainly a kind 
of light green corrosion product, accompanied with harmful powdery, as shown in Figure 6a. SEM observation showed the morphological variations, such as uneven surface, obvious layered structure, loose, few cracks and small crystals with high crystallinity, as shown in Figure 6b. EDS measurements revealed that the chemical compositions containing elements $\mathrm{Cu}, \mathrm{O}$, and $\mathrm{C}$ - especially the high $\mathrm{Cu}$ and $\mathrm{O}$ contents.
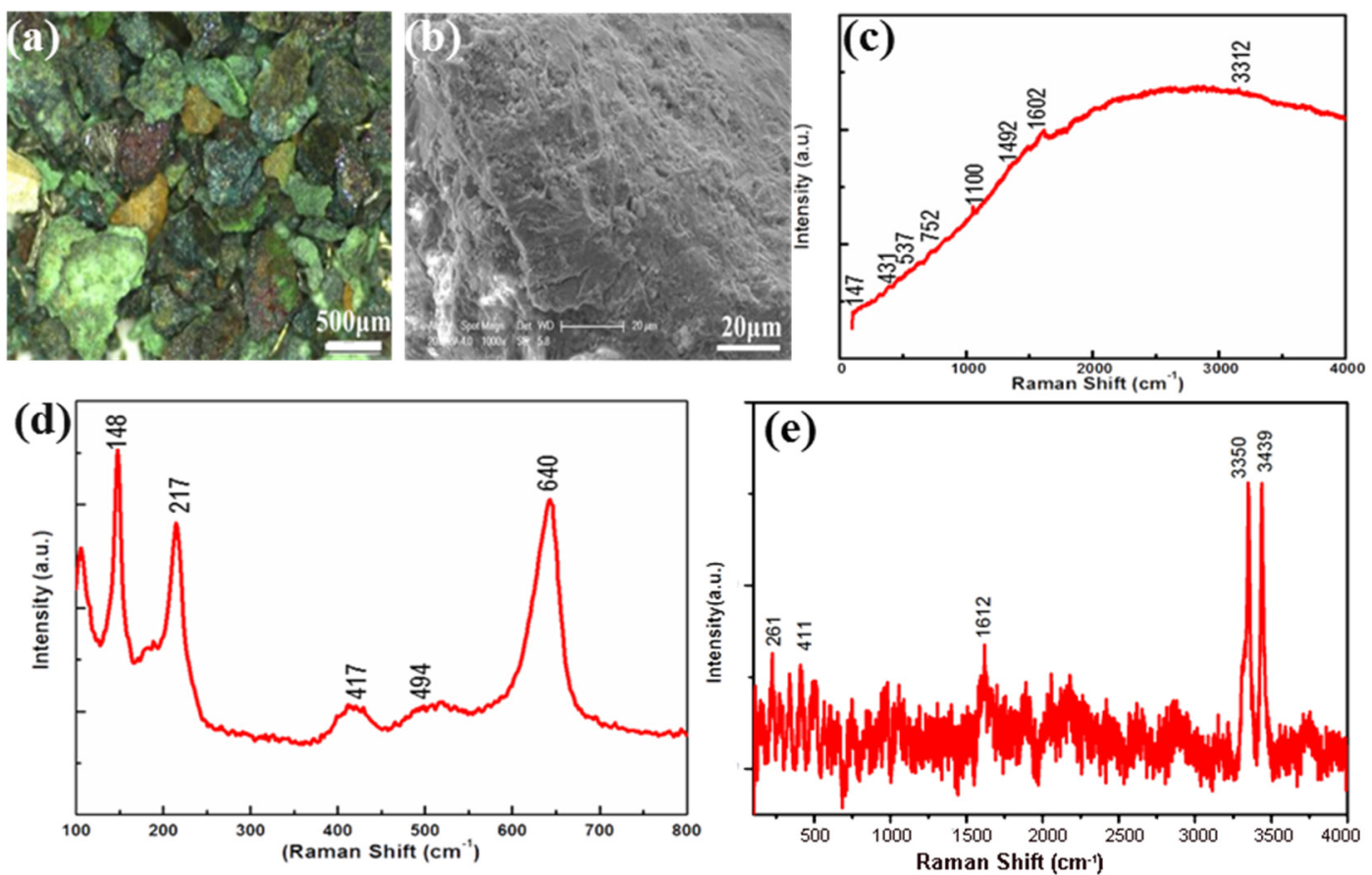

Figure 6. Characterizations of the corrosion products upon the bronze sword (Western Han Dynasty, collection No.: 1938): (a) Optical image; (b) SEM morphology; (c) Raman spectrum of malachite in a range $100-3500 \mathrm{~cm}^{-1}$; (d) Raman spectrum of cuprite in a range $100-800 \mathrm{~cm}^{-1}$; (e) Raman spectrum of atacamite in a range $100-4000 \mathrm{~cm}^{-1}$.

Raman spectra indicated the corrosion products including not only malachite $\left(\mathrm{CuCO}_{3} \cdot \mathrm{Cu}(\mathrm{OH})_{2}\right)$, as shown in Figure $6 \mathrm{c}$ and cuprite $\left(\mathrm{Cu}_{2} \mathrm{O}\right)$, as shown in Figure $6 \mathrm{~d}$, but also atacamite $\left(\mathrm{CuCl}_{2} \cdot 3 \mathrm{Cu}(\mathrm{OH})_{2}\right)$, as shown in Figure 6e. However, they exhibited different crystallinity (i.e., low degree for malachite and high degree for cuprite).

In addition, for the atacamite $\left(\mathrm{CuCl}_{2} \cdot 3 \mathrm{Cu}(\mathrm{OH})_{2}\right)$, the peaks of the combined water at $3350 \mathrm{~cm}^{-1}$ and $3439 \mathrm{~cm}^{-1}$ were very strong, and the peak of free water $\mathrm{H}-\mathrm{O}-\mathrm{H}$ bending vibration at $1612 \mathrm{~cm}^{-1}$ was also observed. Therefore, it could be identified that atacamite was a newly generated "secondary corrosion" stage during museum conservation. From the co-existing relation, the malachite and cuprite belonged to the "primary corrosion" stage.

It is well-known that atacamite is a kind of harmful corrosion for ancient bronzes, and is generally formed in an environment containing a high concentration of chloride ion $\left(\mathrm{Cl}^{-}\right)$.

\subsection{Corrosions on the Bronze Bowl (Bo)}

Figure 7 is experimental results of the corrosion products on the surface of the bronze bowl (Bo) (Tang Dynasty, 618 AD-907 AD, collection No.: 3668). Visually, the bronze was of a surface with green corrosion product, and no trace of harmful powder was observed, as shown in Figure 7a. SEM observation showed a relatively flat surface with small cracks, as shown in Figure 7b. EDS measurement revealed that the chemical compositions involved $\mathrm{Cu}, \mathrm{O}$, and $\mathrm{C}$ elements, and $\mathrm{Cu}$ and $\mathrm{O}$ elements had high contents. 

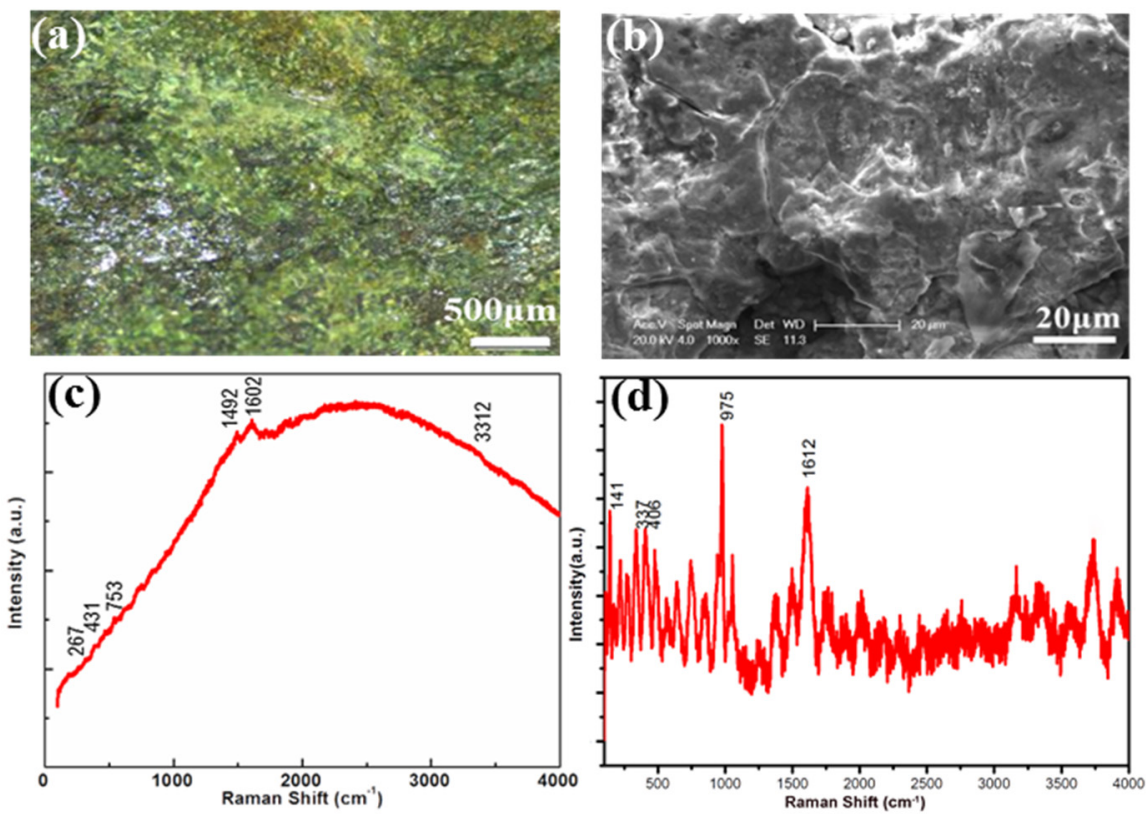

Figure 7. Characterizations of the corrosion products upon the bronze bowl (Bo) from the Tang Dynasty (Collection no.: 3668): (a) Optical image; (b) SEM morphology; (c) Raman spectrum of malachite in a range $100-3500 \mathrm{~cm}^{-1}$; (d) Raman spectrum of brochantite in a range $100-3500 \mathrm{~cm}^{-1}$.

Raman spectra indicated that the corrosion products contained malachite $\left(\mathrm{CuCO}_{3} \cdot \mathrm{Cu}(\mathrm{OH})_{2}\right)$, as shown in Figure $7 \mathrm{c}$, as well as brochantite $\left(\mathrm{CuSO}_{4} \cdot 3 \mathrm{Cu}(\mathrm{OH})_{2}\right)$, as shown in Figure $7 \mathrm{~d}$. Both corrosions had impurity element $\mathrm{Si}$, indicating formation before entering the museum. However, in some portion of the brochantite corrosion, it was found that there was an obvious $\mathrm{H}-\mathrm{O}-\mathrm{H}$ bending vibration peak of free water at $1612 \mathrm{~cm}^{-1}$. It implied the continuous growth of brochantite during museum conservation, i.e., formation of the "secondary corrosion" stage.

\section{Discussion}

When we summed up the above experimental results and consulted the crystallographic and thermodynamic data of the related bronze corrosion products, as listed in Tables 2 and 3 [22,23], the following rules and phenomena could be found:

Table 2. Corrosion products on the surface of the six ancient bronzes.

\begin{tabular}{|c|c|c|c|}
\hline & Sample Number & Primary Corrosion & Secondary Corrosion \\
\hline 1 & $\begin{array}{l}\text { Bronze vase }(\mathrm{Gu})(\text { No.: } \\
\text { ABG-2209-1) }\end{array}$ & $\begin{array}{l}\text { cuprite (cubic), cassiterite (tetrahedral) } \\
\text { and amorphous mixtures }\end{array}$ & malachite (monoclinic) \\
\hline 2 & Bronze goblet (Jue Bei) (No.: 3253) & cuprite (cubic) & malachite (monoclinic) \\
\hline 3 & Bronze basin (Fu) (No.: ABF-5155) & $\begin{array}{l}\text { cuprite (cubic), cassiterite (tetrahedral) } \\
\text { and malachite (monoclinic) }\end{array}$ & azurite (monoclinic) \\
\hline 4 & Bronze vessel (Ding) (No.: 1233) & malachite (monoclinic) and carbon & azurite (monoclinic) \\
\hline 5 & Bronze sword (No.: 1938) & $\begin{array}{l}\text { cuprite (cubic) and malachite } \\
\text { (monoclinic) }\end{array}$ & atacamite (orthohombic) \\
\hline 6 & Bronze bowl (Bo) (No.: 3668) & malachite (monoclinic) & brochantite (monoclinic) \\
\hline
\end{tabular}


Table 3. Crystallographic and thermodynamic information of the corrosion products [22,23].

\begin{tabular}{|c|c|c|c|c|c|c|}
\hline Name & $\begin{array}{l}\text { Molecular } \\
\text { Formula }\end{array}$ & $\begin{array}{l}\text { Chemical } \\
\text { Composition }\end{array}$ & $\begin{array}{l}\text { Crystal System } \\
\text { (Lattice Type) }\end{array}$ & Space Group & Cell Data & $\Delta \mathrm{r} G_{f}^{\Theta}(\mathrm{KJ} / \mathrm{mol})$ \\
\hline Copper & $\mathrm{Cu}$ & $\mathrm{Cu}$ & $\begin{array}{c}\text { Cubic } \\
\text { (face-centered cubic } \\
\text { lattice) }\end{array}$ & $\begin{array}{l}\mathrm{Fm} \overline{3} \mathrm{~m} \\
(\# 225)\end{array}$ & $\begin{array}{c}a=3.615 \AA \\
Z=4\end{array}$ & 0 \\
\hline Cuprite & $\mathrm{Cu}_{2} \mathrm{O}$ & $\mathrm{Cu}: 88.82 \%$ & $\begin{array}{c}\text { Cubic (Simple cubic } \\
\text { lattice) }\end{array}$ & $\operatorname{Pn} \overline{3} \mathrm{~m}(\# 224)$ & $\begin{array}{c}\mathrm{a}=4.2685 \AA \\
\mathrm{Z}=2\end{array}$ & -146.0 \\
\hline Cassiterite & $\mathrm{SnO}_{2}$ & $\begin{array}{l}\mathrm{SnO}_{2}: 99.60 \% \\
\mathrm{Cu}: 0.0014 \%\end{array}$ & $\begin{array}{l}\text { Tetrahedral (Simple } \\
\text { tetragonal lattice) }\end{array}$ & $\mathrm{P}_{2} / \mathrm{mnm}(\# 136)$ & $\begin{array}{c}\mathrm{a}=\mathrm{b}=4.7382 \AA \\
\mathrm{c}=3.1871 \AA \\
\mathrm{Z}=2\end{array}$ & -515.8 \\
\hline $\begin{array}{l}\text { Atacamite } \\
\text { (harmful } \\
\text { corrosion) }\end{array}$ & $\mathrm{CuCl}_{2} \cdot 3 \mathrm{Cu}(\mathrm{OH})_{2}$ & $\begin{array}{c}\text { Cu: } 59.51 \%, \\
\text { H: } 1.42 \%, \\
\text { Cl: } 22.47 \%, \\
\text { O: } 16.60 \%\end{array}$ & $\begin{array}{l}\text { Orthohombic (Simple } \\
\text { orthorhombic lattice) }\end{array}$ & $\begin{array}{l}\text { Pnam } \\
(\# 62)\end{array}$ & $\begin{array}{c}\mathrm{a}=6.030 \AA \\
\mathrm{b}=9.120 \AA \\
\mathrm{c}=6.865 \AA \\
\mathrm{Z}=4\end{array}$ & -1339.5 \\
\hline Malachite & $\mathrm{CuCO}_{3} \cdot \mathrm{Cu}(\mathrm{OH})_{2}$ & $\begin{array}{c}\mathrm{CuO}: 71.95 \% \\
\mathrm{CO}_{2}: 19.90 \% \\
\mathrm{H}_{2} \mathrm{O}: 8.15 \%\end{array}$ & $\begin{array}{l}\text { Monoclinic (Simple } \\
\text { monoclinic lattice) }\end{array}$ & $\begin{array}{l}\mathrm{P} 2_{1} / \mathrm{c} \\
(\# 14)\end{array}$ & $\begin{array}{c}\mathrm{a}=9.502 \AA \\
\mathrm{b}=11.974 \AA \\
\mathrm{c}=3.240 \AA \\
\beta=98^{\circ} 45^{\prime} \\
\mathrm{Z}=4\end{array}$ & -893.6 \\
\hline Azurite & $2\left(\mathrm{CuCO}_{3}\right) \cdot \mathrm{Cu}(\mathrm{OH})_{2}$ & $\begin{array}{c}\mathrm{CuO}: 69.24 \% \\
\mathrm{CO}_{2}: 25.53 \% \\
\mathrm{H}_{2} \mathrm{O}: 5.23 \%\end{array}$ & $\begin{array}{c}\text { Monoclinic } \\
\text { (Simple monoclinic } \\
\text { lattice) }\end{array}$ & $\begin{array}{l}\mathrm{P} 21 / \mathrm{c} \\
(\# 14)\end{array}$ & $\begin{array}{c}\mathrm{a}=5.0109 \AA \\
\mathrm{b}=5.8485 \AA \\
\mathrm{c}=10.345 \AA \\
\beta=92.43^{\circ} \\
\mathrm{Z}=2\end{array}$ & -1315.5 \\
\hline Brochantite & $\mathrm{CuSO}_{4} \cdot 3 \mathrm{Cu}(\mathrm{OH})_{2}$ & $\begin{array}{c}\text { Cu: } 56.20 \%, \\
\text { H: } 1.34 \%, \\
\text { S: } 7.09 \%, \\
\text { O: } 35.37 \%\end{array}$ & $\begin{array}{c}\text { Monoclinic } \\
\text { (Simple monoclinic } \\
\text { lattice) }\end{array}$ & $\begin{array}{l}\mathrm{P} 2_{1} / \mathrm{c} \\
(\# 14)\end{array}$ & $\begin{array}{c}\mathrm{a}=6.02 \AA \\
\mathrm{b}=9.85 \AA \\
\mathrm{c}=13.08 \AA \\
\beta=103^{\circ} 22^{\prime} \\
\mathrm{Z}=4\end{array}$ & -1817.7 \\
\hline
\end{tabular}

(1) The crystalline lattice of the corrosive products tended to have a transformation from a high symmetry of the "primary corrosion" stage to a low symmetry of the "secondary corrosion" stage. For example, the cubic crystal system of cuprite $\left(\mathrm{Cu}_{2} \mathrm{O}\right)$ as the "primary corrosion" stage transformed into the monoclinic crystal system of malachite $\left(\mathrm{CuCO}_{3} \cdot \mathrm{Cu}(\mathrm{OH})_{2}\right)$ as the "secondary corrosion" stage for the bronze vase (Gu) (No.: ABG-2209-1) and bronze goblet (Jue Bei) (No.: 3253), or into the orthogonal crystal system of atacamite $\left(\mathrm{CuCl}_{2} \cdot 3 \mathrm{Cu}(\mathrm{OH})_{2}\right)$ as the "secondary corrosion" stage for the bronze sword (No.: 1938).

(2) This transformation could also happen in between the same crystal system, such as from the monoclinic system of malachite $\left(\mathrm{CuCO}_{3} \cdot \mathrm{Cu}(\mathrm{OH})_{2}\right)$ as the "primary corrosion" stage into the same system of azurite $\left(2\left(\mathrm{CuCO}_{3}\right) \cdot \mathrm{Cu}(\mathrm{OH})_{2}\right)$ as the "secondary corrosion" stage for the Bronze vessel (Ding) (No.: 1233), or brochantite $\left(\mathrm{CuSO}_{4} \cdot 3 \mathrm{Cu}(\mathrm{OH})_{2}\right)$ as the "secondary corrosion" stage for the Bronze bowl (Bo) (No.: 3668).

(3) In addition, these transformations also met the Gibbs free energy reduction theory [24]. The theory describes that, for a closed system without any other work, the Gibbs free energy of the system always decreases in an irreversible reaction process under a certain temperature and pressure, and the system reaches to an equilibrium state in which the Gibbs free energy assumes the minimum value.

More interestingly and importantly, these transformation rules happened perfectly in accordance with the physical law of "spontaneous symmetry-breaking" [15].

In general, when the environment contains free $\mathrm{CO}_{2}$ and water vapor, the cubic crystal system of cuprite $\left(\mathrm{Cu}_{2} \mathrm{O}\right)$ tends to generate the monoclinic crystal system of malachite $\left(\mathrm{CuCO}_{3} \cdot \mathrm{Cu}(\mathrm{OH})_{2}\right)$, according to the following chemical reaction:

$$
\mathrm{Cu}_{2} \mathrm{O}_{(\mathrm{cr})}+1 / 2 \mathrm{O}_{2(\mathrm{~g})}+\mathrm{H}_{2} \mathrm{O}_{(\mathrm{l})}+\mathrm{CO}_{2(\mathrm{~g})}=\mathrm{CuCO}_{3} \cdot \mathrm{Cu}(\mathrm{OH})_{2(\mathrm{cr})}
$$

where $\Delta \mathrm{r} G_{f}^{\Theta}=-116.112 \mathrm{KJ} / \mathrm{mol}$. The system's Gibbs function is less than zero $\left(\Delta \mathrm{r} G_{f}^{\Theta}<0\right)$, which means that the reaction can occur spontaneously. This is a common corrosion transformation in the preservation of ancient bronzes. 
However, for the bronze sword (No.: 1938), where the external environment contained excessive high $\mathrm{Cl}^{-}$concentration, the cubic crystal system of cuprite $\left(\mathrm{Cu}_{2} \mathrm{O}\right)$ was also of possibility to transform into the orthogonal crystal system of atacamite $\left(\mathrm{CuCl}_{2} \cdot 3 \mathrm{Cu}(\mathrm{OH})_{2}\right)$ [25], regarding the following reaction:

$$
2 \mathrm{Cu}_{2} \mathrm{O}_{(\mathrm{cr})}+\mathrm{O}_{2(\mathrm{~g})}+\mathrm{H}_{2} \mathrm{O}_{(\mathrm{l})}+\mathrm{HCl}_{(\mathrm{ai})}=\mathrm{CuCl}_{2} \cdot 3 \mathrm{Cu}(\mathrm{OH})_{2}(\mathrm{cr})
$$

where $\Delta \mathrm{r} G_{f}^{\Theta}=-715.072 \mathrm{KJ} / \mathrm{mol}$. The physical state of each substance is indicated as cr (crystalline solid), 1 (liquid), $g$ (gas), $a_{i}$ (electrolyte in the ionized standard state) or $a_{0}$ (electrolyte in the unionized standard state).

Alternatively, in case of the bronze basin (Fu) (No.: ABF-5155), bronze vessel (Ding) (No.: 1233) and bronze bowl (Bo) (No.: 3668), both "primary corrosion" and "secondary corrosion" stages belonged to the monoclinic crystal system, which could also be explained by the law of "spontaneous symmetry-breaking" and the Gibbs free energy reduction. In fact, when the corrosion products had the same crystalline characters in crystal type, spatial structure and symmetry, their internal energy difference would be very small, which was caused by the different ion stacking arrangement. Therefore, it naturally provided a possibility of the inter-transformation among these corrosion products, and the desired products mainly depended on the corresponding gas or ion concentration in the environment. This also explained why there was often a co-existence (or symbiosis) of malachite, azurite and brochantite in mineral deposits. Some examples are given below:

(1) In the case of high $\mathrm{CO}_{2}$ concentration and a low $\mathrm{PH}$ value in the environment, malachite $\left(\mathrm{CuCO}_{3} \cdot \mathrm{Cu}(\mathrm{OH})_{2}\right)$ would transform into azurite $\left(2\left(\mathrm{CuCO}_{3}\right) \cdot \mathrm{Cu}(\mathrm{OH})_{2}\right)$, while in the case of low $\mathrm{CO}_{2}$ concentration in a humid environment, azurite would transform into malachite, according to the following chemical reaction [21]:

$$
2\left[2\left(\mathrm{CuCO}_{3}\right) \cdot \mathrm{Cu}(\mathrm{OH})_{2}\right]_{(\mathrm{cr})}+\mathrm{H}_{2} \mathrm{O}_{(\mathrm{l})}=3\left[\mathrm{CuCO}_{3} \cdot \mathrm{Cu}(\mathrm{OH})_{2}\right]_{(\mathrm{cr})}+\mathrm{CO}_{2(\mathrm{~g})}
$$

where $\Delta \mathrm{rG}_{f}^{\Theta}=-207.03 \mathrm{KJ} / \mathrm{mol}$.

(2) When the environment contains a certain concentration of $\mathrm{SO}_{4}{ }^{2-}$, malachite $\left(\mathrm{CuCO}_{3} \cdot \mathrm{Cu}(\mathrm{OH})_{2}\right)$ will change into brochantite $\left(\mathrm{CuSO}_{4} \cdot 3 \mathrm{Cu}(\mathrm{OH})_{2}\right)$, according the specific reaction:

$$
2\left[\mathrm{CuCO}_{3} \cdot \mathrm{Cu}(\mathrm{OH})_{2}\right]_{(\mathrm{cr})}+\mathrm{SO}_{4}{ }^{2-}{ }_{(\mathrm{a} 0)}+2 \mathrm{OH}^{-}{ }_{(\mathrm{a} 0)}=\left[\mathrm{CuSO}_{4} \cdot 3 \mathrm{Cu}(\mathrm{OH})_{2}\right]_{(\mathrm{cr})}+2 \mathrm{CO}_{3}{ }^{2-}{ }_{(\mathrm{a} 0)}
$$

where $\Delta \mathrm{r} G_{f}^{\Theta}=-27.102 \mathrm{KJ} / \mathrm{mol}$. Practically, in the case of museum conservation, the $\mathrm{SO}_{4}{ }^{2-}$ concentration in the atmosphere was generally too low to have the reaction in Equation (4) occur. However, at the coast or in industrial areas with a strong air pollution, a high concentration of $\mathrm{SO}_{4}{ }^{2-}$ in the atmosphere could lead to the sulfate corrosion products.

Based on above discussion, this research provides us a possibility to predict the corrosion stages in advance by controlling the conservation conditions of ancient bronzes (i.e., make the corrosion predictable and controllable). For example, we could control the corrosion stage toward the desired direction and avoid the harmful products by consciously adjusting the appropriate preservation environment. This provides a novel route and concept for the corrosion removal and later protection of ancient bronzes.

Therefore, we proposed a protection scheme of ancient bronzes from two aspects:

(1) For the harmless "primary corrosion" stage, prevent it from developing into the harmful corrosion stages, or generate the harmless "secondary corrosion" stage by adjusting the protection environments.

(2) In the case of the harmful "primary corrosion" stage, to make the "secondary corrosion" stage harmless by reasonably controlling the atmospheric gas and ion concentration of the protection environment. For example, when the "primary corrosion" stage is an orthorhombic system of atacamite $\left(\mathrm{CuCl}_{2} \cdot 3 \mathrm{Cu}(\mathrm{OH})_{2}\right)$ or monoclinic system of clinoatacamite $\left(\mathrm{Cu}_{2}(\mathrm{OH})_{3} \mathrm{Cl}\right)$, it could be converted into a monoclinic system of malachite $\left(\mathrm{CuCO}_{3} \cdot \mathrm{Cu}(\mathrm{OH})_{2}\right)$. 
In other words, the Gibbs free energy reduction only provides a criterion for the reaction direction in conditions of isothermal and isobaric processes without non-volume work and has limitations for the corrosion transformation in case of ancient bronze conservation in a complex environment. Therefore, the law of "spontaneous symmetry-breaking" exhibited a universal criterion for corrosion growth in real-world conditions and provided a new theoretical guidance for the later preservation and protection of ancient bronzes.

In fact, this corrosion transformation variation regarding the law of "spontaneous symmetry-breaking" is also suitable for "primary corrosion" growth from fresh bronze, as listed in Table 3.

In a broad sense, it may be a very interesting topic that the law of "spontaneous symmetry-breaking" exists in all kinds of metal corrosions. This is because the phenomenon of "symmetry-breaking" or crystal symmetry reduction in corrosion variation is different from regular phase transformation. It exhibits not only changes in crystal structures, but also in chemical compositions due to chemical reactions. These are questions that need to be addressed in the next work.

\section{Conclusions}

Corrosion on the surface of ancient bronzes is a complicated process. Experimental results revealed that, when the "secondary corrosion" stage arises from the "primary corrosion" stage during museum preservation, it exhibits transformation relationships related to the physical law of "spontaneous symmetry-breaking". That is, from a high symmetry crystal system to a low symmetry crystal system, or inter-transformation or symbiosis in the case of the same symmetry crystal types of corrosions. Thermodynamically, this transformation also follows the principle of the Gibbs free energy reduction, which indicates the reaction direction of corrosions.

With regard to these new phenomena and rules, ancient bronze corrosion can be predictable and controllable through adjusting the conservation conditions (e.g., humidity, atmospheric gases and ion concentrations), which will be experimentally studied further.

Author Contributions: C.P. (conceiving the project and writing the final paper). Y.Y. (writing the final paper and analyzing the data). X.C. (writing initial drafts of the work and analyzing the data). Y.L. (performing the experiments, characterizing the samples, and analyzing the data). Z.W. (characterizing one sample). B.L. (participating in the discussion). X.J. (giving expert comments on the manuscript and participating in the discussion). J.J. (giving expert comments on the manuscript and participating in the discussion). All authors have read and agreed to the published version of the manuscript.

Funding: This work was financially supported by the Major Projects of National Social Science Fund of China (No.: 15ZBD032), the National Social Science Fund of China (No.: 17CKG020), and Chinese Universities Scientific Fund.

Acknowledgments: Wuhan Museum and Anlu Museum provide the bronze samples; Shenzhen Research Institute of Wuhan University (project no. JCYJ20170303170542173) supports the Article Processing Charges.

Conflicts of Interest: The authors declare no conflict of interest.

\section{References}

1. Liao, Y. Research on erosion mechanism of bronze cultural relics and transform agent on harmful rust. Sci. Conserv. Archaeol. 2003, 15, 20-23.

2. Scott, D.A. Bronze disease: A review of some chemical problems and the role of relative humidity. J. Am. Inst. Conserv. 1990, 29, 193-206. [CrossRef]

3. Ingo, G.M.; Caro, T.D.; Riccucci, C.; Angelini, E.; Grassini, S.; Balbi, S.; Bernardini, P.; Salvi, D.; Bousselmi, L.; Cilingiroglu, A.; et al. Large scale investigation of chemical composition, structure and corrosion mechanism of bronze archeological artefacts from Mediterranean basin. Appl. Phys. A 2006, 83, 513-520. [CrossRef]

4. Bosi, C.; Garagnani, G.L.; Imbeni, V.; Martini, C.; Mazzeo, R.; Poli, G. Unalloyed copper inclusion in ancient bronze artifacts. J. Mater. Sci. 2002, 37, 4285-4298. [CrossRef]

5. Robbiola, L.; Blengino, J.M.; Fiaud, C. Morphology and mechanisms of formation of natural patinas on archaeological Cu-Sn alloys. Corros. Sci. 1998, 40, 2083-2111. [CrossRef] 
6. Feng, S.B.; Hu, F.H.; Feng, L.T. Research status of corrosion of bronze wares. Corros. Prot. 2009, 30, 7-10.

7. Frankel, G.S. Pitting corrosion of metals: A review of the critical factors. J. Electrochem. Soc. 1998, 145, 2186-2198. [CrossRef]

8. Edwards, M.; Ferguson, J.F.; Reiber, S.H. The pitting corrosion of copper. J. Am. Water Work. Assoc. 1994, 86, 74-90. [CrossRef]

9. Zhang, X.M.; Yuan, S.X.; Liu, Y.; Zhou, B.Z. Research on the corrosion of bronzes from Zhouyuan Site and Yu State cemeteries. Sci. Conserv. Archaeol. 1999, 11, 7-18.

10. Galvele, J.R.; Dedemicheli, S.M. Mechanism of intergranular corrosion of Al-Cu alloys. Corros. Sci. 1970, 10, 795-807. [CrossRef]

11. Culpan, E.A.; Foley, A.G. The detection of selective phase corrosion in cast nickel aluminium bronze by acoustic emission techniques. J. Mater. Sci. 1982, 17, 953-964. [CrossRef]

12. Ingo, G.M.; Caro, T.D.; Riccucci, C.; Khosroff, S. Uncommon corrosion phenomena of archaeological bronze alloys. Appl. Phys. A 2006, 83, 581-588. [CrossRef]

13. Kosec, T.; Ćurković, H.O.; Legat, A. Investigation of the corrosion protection of chemically and electrochemically formed patinas on recent bronze. Electrochim. Acta 2010, 56, 722-731. [CrossRef]

14. Couture-Rigert, D.E.; Sirois, P.J.; Moffatt, E.A. An investigation into the cause of corrosion on indoor bronze sculpture. Stud. Conserv. 2012, 57, 142-163. [CrossRef]

15. Popkov, V.; Evans, M.R.; Mukamel, D. Spontaneous symmetry breaking in a bridge model fed by junctions. J. Phys. A-Math Theor. 2008, 41, 1751-8113. [CrossRef]

16. Großkinsky, S.; Schütz, G.M.; Willmann, R.D. Rigorous Results on Spontaneous Symmetry Breaking in a One-Dimensional Driven Particle System. J. Stat. Phys. 2007, 128, 587-606. [CrossRef]

17. Yao, N.Y.; Potter, A.C.; Potirniche, I.D.; Vishwanath, A. Discrete Time Crystals: Rigidity, Criticality, and Realizations. Phys. Rev. Lett. 2017, 118, 030401. [CrossRef]

18. Chen, S.P.; Wang, C.F.; Zhou, H.T.; Tan, Y.H.; Wen, H.R.; Tang, Y.Z. Symmetry breaking and switchable thermal dielectric behaviors triggered by order-disorder phase transition in a neutral co-crystallized organic adduct. Chem. Phys. Lett. 2018, 715, 45-50. [CrossRef]

19. Frost, R.L.; Martens, W.N.; Rintoul, L.; Mahmutagic, E.; Kloprogge, J.T. Raman spectroscopic study of azurite and malachite at 298 and 77 K. J. Raman Spectrosc. 2002, 33, 252-259. [CrossRef]

20. Bersani, D.; Lottici, P.P. Raman spectroscopy of minerals and mineral pigments in archaeometry. J. Raman Spectrosc. 2016, 47, 499-530. [CrossRef]

21. Wu, T.T.; Meng, W.W.; Bao, Z.R.; Li, Y.; Pan, C.X. Study of synthesizing malachite corrosion product on the bronze surface in excessive $\mathrm{CO}_{2}$ atmosphere environment. J. Chin. Soc. Corr. Prot. 2014, 34, 82-88. (In Chinese)

22. Anthony, J.W.; Bideaux, R.A.; Bladh, K.W.; Nichols, M.C. Handbook of Mineralogy; Mineralogical Society of America: Chantilly, VA, USA, 1990. Available online: http://www.handbookofmineralogy.org/ (accessed on 5 October 2019).

23. Wagman, D.D.; Evans, W.H.; Parker, V.B.; Schumm, R.H.; Halow, I.; Bailey, S.M.; Churney, K.L.; Nuttal, R.L. The NBS tables of chemical thermodynamic properties. J. Phys. Chem. Ref. Data 1982, 11, 1807-1812.

24. MacLeod, I.D. Bronze disease: An electrochemical explanation. ICCM Bull. 1981, 7, 16-26. [CrossRef]

25. He, L.; Liang, J.Y.; Zhao, X.; Jiang, B.L. Corrosion behavior and morphological features of archeological bronze coins from ancient China. Microchem. J. 2011, 99, 203-212. [CrossRef]

(C) 2020 by the authors. Licensee MDPI, Basel, Switzerland. This article is an open access article distributed under the terms and conditions of the Creative Commons Attribution (CC BY) license (http://creativecommons.org/licenses/by/4.0/). 